\title{
ECONOMIC CLUSTERS OR CULTURAL COMMONS? THE LIMITS OF COMPETITION-DRIVEN DEVELOPMENT IN THE ECUADORIAN ANDES
}

\author{
Rudi Colloredo-Mansfeld \\ University of North Carolina, Chapel Hill \\ Jason Antrosio \\ Hartwick College
}

\begin{abstract}
We examine here two Ecuadorian towns and the state's efforts to support their development through competitiveness initiatives. Neoliberal, economic globalization is often equated with the insecurities of market competition. However, economic policy makers do not foment competition as much as competitive advantage. Whereas competition requires individual know-how, competitive advantage often involves cooperating to improve the underlying factors that help whole groups of firms. In Ecuador, policies have sought to engineer competitive advantage by creating industrial clusters. In our study, the town of Atuntaqui embraced the idea of clusters, uniting firms to work with international consultants and the Ministry of Industry. The economy has improved, but wealth shows signs of consolidation. The comparative case is a mechanized indigenous craft economy in Otavalo. Exploring how Otavalo's development has generated a set of shared resources anchored in a market plaza, we argue that its economy is best understood as a cultural commons. The experiences of both places have shown that economic development must take explicit measures to defend such commons if the gains of strategic cooperation are to be sustained in the long run.
\end{abstract}

In 2001, a small group of clothing manufacturers launched the new trade show Expoferia in the Andean town of Atuntaqui. Elsewhere in Ecuador, manufacturers in all sectors were reeling from the 2000 dollarization of the economy. This abandonment of the national currency and associated fiscal reforms were bankrupting hundreds of textile operators, furniture makers, and other small businesses. Producers in Atuntaqui, though, worked with renewed energy. Backed by national television advertising, their Expoferia drew an estimated twenty thousand attendees in its first year and grew to attract one hundred thousand by 2006. Manufacturers went on a building spree, opening new showrooms along the town's main avenues. Governments at both local and national levels got on board. Promoting Atuntaqui's fashion along with the country's more famous bananas and cut flowers, Ecuador's consulates issued press reports 
on the town's sales (Consulado General del Ecuador en Montreal 2003). Delegations from other provincial towns came calling on the local chamber of commerce, trying to learn the secret of Atuntaqui's turnaround.

What lies behind Atuntaqui's success? When we asked the mayor of Atuntaqui during an interview in 2005, he responded, "Coming together in associations." For his town or any town to get ahead, what Mayor Yepez wanted to know was, "How can we successively structure a cluster that brings together however many, one, two, three, ten, twenty-five? The important thing is that we arrive with a better capacity, to create the capacity to build something, to initiate a change in mentality."

In scholarly literature, the definition of a cluster is quite dry: "Firms engaged in traded and untraded relationships with each other, with suppliers of specialized services and knowledge inputs and infrastructure and with governments and consumers" (Wolfe and Lucas 2005, 1). But in Atuntaqui, the cluster became a new rallying cry of solidarity. As Yepez explained to a trade group in a neighboring town: "For me the most fundamental thing ... is to demonstrate this power of the people: associating with others is the only concept in the whole world."

Meanwhile, in nearby Otavalo, one of the Andes' success stories of competitive entrepreneurship was unraveling. Since the 1940s, Quichuaspeaking, native Otavaleño weavers and vendors had transformed a provincial marketplace into a center of commercial growth and cultural innovation. The anthropologist Lynn Meisch (2002) documented that, in the mid-1990s, nine air cargo companies operated in Otavalo, shipping more than 1,500 tons of merchandise annually. The most popular product, hand-knit sweaters, grossed more than $\$ 15$ million a year. The dollarization, though, eliminated foreign-exchange advantages and exposed the market to cheap imports. Although a few trades have once again begun to expand, many producers have struggled. In 2005, artisan leaders signed on to the government-sponsored program Participatory Assessment of Competitive Advantage, hoping, in part, to use ideas applied in Atuntaqui to restore sales in Otavalo. These examples from the Ecuadorian Andes reveal a social dimension of neoliberal capitalism largely overlooked in much critical scholarship. Anthropological writings, for example, dwell on global-driven markets as amoral and ruthless. Thus, the Comaroffs $(2000,298)$ introduce their Millennial Capitalism as follows: Neoliberal capitalism "appears both to include and to marginalize in unanticipated ways; to produce desire and expectation on a global scale (Trouillot 1999) yet to decrease the certainty of work or security of persons; to magnify class differences but to undercut class consciousness; above all to offer up vast, almost instantaneous riches to those who master its spectral technologiesand simultaneously to threaten the very existence of those who do not."

The Comaroffs develop their analysis to suggest that modern capitalism has become so capricious, so dislodged from social worlds of produc- 


\section{Latin American Research Review}

tion, that it has become an occult force. The new spirit of capitalism is not Weber's Protestant ethic but a dark, external agency that strikes at random for good or ill. Bourdieu, for his part, still saw something of an oppressive rationality at work. He characterized neoliberalism as $(1998,35)$ "an unfettered capitalism without any disguise but rationalized, pushed to the limit of its economic efficacy by the introduction of modern forms of domination, such as 'business administration' ... market research and advertising."

In provincial Latin America, however, the new realities of capitalism arrive neither in the dazzle of big payouts nor couched in the science of markets. Rather, the future of livelihoods is being addressed in workshops that teach competitors about unity and collaboration. To put a finer point on it, in an era of free trade, economists and ministers of industry do not promote competition but competitive advantage (Porter 1998). Whereas competition requires individual know-how and hustle, competitive advantage involves the underlying factors that enhance the position of whole groups of firms. This conceptual distinction has put in motion government-backed programs of cooperation and strategic alliances that can remake local economic communities (Drabenstott, Novack, and Weiler 2004; Wolfe and Lucas 2005). In Ecuador, Atuntaqui symbolizes the rewards for getting it right. Otavalo's troubles, though, are a reminder of how the benefits of competitive entrepreneurship can dry up-at precisely that moment when promarket liberalism is meant to champion it. The recent histories of these towns raise a complex question: what keeps competitors from turning on one another and destroying the value they create through their interactions? More pointedly, is it possible for the creativity, skills, and resources that have been created through a group of producers' efforts to remain anchored in such places as small Andean cities even as they are pressured by globalization?

Case studies of small-time industrial clusters in developing countries both demonstrate the power of grouping and underscore its unpredictability. Garment makers in Lima, Peru, for example, grew strongly in the 1980s and then stagnated in the 1990s (Visser 2000). In Brazil, a cluster of export-oriented shoe-making enterprises in the 1970s transformed to include a few big firms with international presence in the 1990s (Schmitz 1995). African clusters in fishing and related trades, on the other hand, rarely launch any enterprise to prominence (Mitullah 1999). Schmitz and Nadvi (1999) argue that these variations do not weaken the importance of clustering but rather highlight the potency of carefully conceived joint action. Yet if coordination among producers can solve raw material problems or skilled labor shortages and the like, such joint action still leaves unsolved how to realize the promise of a cluster: to stabilize and reproduce a "culture of productivity" through time (Porter 2000, 25). 
We argue that these examples from the Ecuadorian Andes offer an alternative model of a plausible, place-based economy. Rather than an industrial cluster, the model is better considered a cultural commons. In contrast to a cluster's vision of cooperation engineered for specific economic goals, a commons perspective puts at its center both a shared, exploitable resource and the stewardship needed to regenerate it. We come to the idea of a commons amid the concept's rebirth. Scholars now write about the digital commons, the scientific commons, and the health commons, as well as natural commons (Lessig 2001; Nonini 2007). By bridging such different domains with a single idea, they draw attention to a core claim: that social groups survive, in part, because of the knowledge and resources handed down to them, which they must hold in trust for the next generation. In much of this work, writers pit the virtues of the commons against the greed of the market. That is, they warn that different types of public domains are at risk of succumbing to corporate takeovers, that common use is being lost to private profit, and that privatization pushes aside community management.

Our goal here is to bridge the apparent opposition of market and commons. We describe how a regional market works as a commons in three crucial ways: first, competitors (who in fact may not cooperate in systematic ways) combine imitation and innovation to cogenerate a shared economic value; second, commercial goods and places produced through competition can become culturally marked and defended as community patrimony; and, third, markets that have built distinctive products identified with a people and place can fail the way commons do: through overexploitation, free riders, and incursion by newcomers. Indeed, regulated by cultural conventions and voluntary associations, the success of an economic commons is precarious at best. Now with government-orchestrated clusters, commons may face a new threat of enclosure.

Concerned to show this vulnerability, we acknowledge, though, that the contrasts between clusters and commons should not be overdrawn. If different, they are not opposed. Both concern how commercial rivalry consolidates into collectivities of self-generating cultural and economic development. Both entail finding a balance between competing and cooperating; and both see connections between economic productivity and collective identities. A commons perspective, though, goes further. It acknowledges the value of economic resources that accrue at the community level and points out the political role that communities must play in their defense.

A note on the information presented here. The project on Otavalo textile trades began in 2001. In the wake of the fiscal reforms, we explored the connections between innovation and economic success. We surveyed forty-one producers (twenty-one mechanized sweater operations and twenty skilled weavers of wall hangings) about their initial investments, 
their exports since the reforms, their design practices, and their assessment of the current market. Otavalo's largest artisan union, the Unión de Artesanos Indígenas del Mercado Centenario de Otavalo (UNAIMCO) collaborated with the project, opened their meetings to us, and ultimately used our information in their programming. In 2005, we followed up by expanding to Atuntaqui. Investigating perspectives on each town's competitive advantages, we interviewed fifty-one shirtmakers in Otavalo and sixty-eight shirtmakers in Atuntaqui. As in Otavalo, we worked with a key producer group in Atuntaqui, collaborating with the chamber of commerce in a study for a design center. We augment core 2001 and 2005 surveys with additional interviews, observations, and conversations recorded during our combined eleven trips and seventeen months of fieldwork undertaken between 2001 and 2007.

In the first part of the article, we describe how Atuntaqui's apparel producers moved from passive to active cooperation to avidly embrace a cluster model. In the second part of the article, we examine Otavalo's mechanized, craft economy to develop the alternative idea of a market commons. In the final section, we track recent developments in Atuntaqui, showing that a cultural commons model helps account for the patterns of private and civic investment in Atuntaqui.

\section{FROM FACTORY TOWN TO TEXTILE CLUSTER, ATUNTAQUI, 1965-2005}

In Atuntaqui, before there were clusters, there was the giant factory Fábrica Imbabura. Spanish investors set up the textile operation in the 1920s, creating its own hydroelectric plant, shipping in hundreds of machines from England and the United States, and ultimately creating the first modern, industrial workforce in the region. Indeed, the mayor's very job came into existence in the 1930s when the province recognized the importance of the factory and granted Atuntaqui and five neighboring parishes formal political jurisdiction as a township (cantón).

In the ensuing years, the township consolidated politically while the factory faltered economically. In the early 1960s, the plant still nominally employed nearly six hundred workers and the rhythm of the town's day was marked by the factory's whistle, an old air-raid warning siren that had been imported from Europe. Yet the plant was no longer profitable. In July 1965, workers who had long gone unpaid escalated a months-long strike and stormed the plant office. Although the state intervened on the workers' behalf, it could not establish new terms under which mass production could continue. As employment collapsed, the internal capacities of the factory-most notably a pool of skilled labor-unbundled into a new external economy.

Atuntaqui already nurtured a small collection of home-based manufacturers alongside the main plant. Some enterprising retirees had invested 
in manual knitting machines and churned out fabric for tejidos (weavings), primarily shawls and ponchos. With a sudden surplus of labor in the 1960s, these tejido operations expanded and were joined by new ones. By the mid-1970s, about sixty shops were operating.

Their individual successes contributed to some shared benefits. Writers on business clusters emphasize such externalities, recovering Marshall's insights into the value of industrial districts (Caniëls and Romijn 2004). At a minimum, an established commercial center amasses "a pool of specialized workers, easy access to suppliers of specialized inputs and services and the quick dissemination of new knowledge" (Schmitz and Nadvi 1999, 1504). Some industrial groupings, however, go beyond the minimum. Schmitz and Nadvi $(1999,1504)$ offer the term collective efficiency to bring together both the incidental and deliberate effects of clustering, defining it as "the competitive advantage derived from both external economies and joint action." More succinctly, clustering entails passive and active gains: "those that fall into the producer's lap and those that require joint efforts" (Schmitz and Nadvi 1999, 1505).

Until the 1990s, Atuntaqui producers mostly relied on those benefits that fell into their laps. Grouped businesses, for instance, attracted a supplier of industrial sewing machinery (Mainco) and a provider of acrylic, cotton, and polyester fiber (Dytex), which both opened Atuntaqui branches in the 1980s. Local workshops competed for seamstresses, thus creating a job market that lured young women from throughout the township. The growing output of goods also attracted indigenous resellers who began to retail sweaters to Colombians. And over time, with Atuntaqui's next generation getting into the family business, the apparel economy diversified away from tejidos and into T-shirts, sweatshirts, and other casual wear (see figure 1).

None of this interaction, though, inspired fashion innovation or created a marketable reputation for Atuntaqui. In fact, road signs on the Pan-American Highway did not list Atuntaqui among northbound destinations for travelers setting out from Quito. In the course of our design survey in 2005, young producers criticized sweater designs of the 1990s as unimaginative. "Folkloric," said one woman, dismissing the very idea of fashionableness. Mayor Yepez said to us in 2005 that, back in 1999, a group of producers came to him claiming the market had stagnated. "If you do not help us, we will die," he reported them saying.

Active cooperation began in earnest in 2001. The effort combined internal initiatives with external support of international donors and government agencies. In table 1, we offer nine characteristics to distinguish two modes of cooperation at work in both Atuntaqui and Otavalo throughout the initiatives launched during the 2000s. The first mode, stewardship, we link to the commons. It involves cultivating nonexclusive resources, access to which depends on belonging to place. The second mode, stra- 


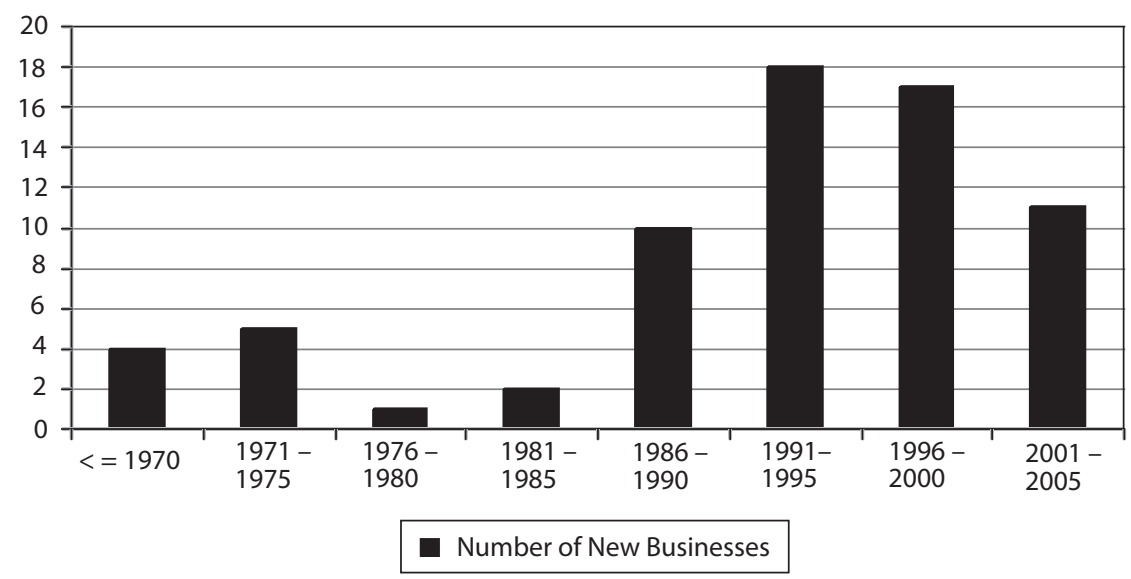

Figure 1 Growth in Atuntaqui Sporting Goods Businesses, 1965-2005

tegic cooperation, relates to cluster development as it came to be pushed in Ecuador. Although it too focuses on shared resources, the payoffs to cooperation are far more divisible and internal-firms are able to capture them. The more Atuntaqui business leaders looked for support from the Ministry of Foreign Trade, Industrialization, Fisheries and Competitiveness (MICIP) and its program Assistance to Small and Medium-Size Enterprises through Support of Clusters, the more this second mode came to the fore. ${ }^{1}$

To begin with, at the mayor's urging, about twenty firms worked with municipal authorities to create Expoferia. Unlike previous textile fairs, Expoferia would showcase designs, firms, and the town itself-the joint marketing of a shared enterprise (table 1, characteristic 6) —and not cheap sales. The team built the programming around fashion shows, music, and Andean dancing, scheduling it all for carnival in February 2001, when Quiteños would leave the city on holiday. According to the account Mayor Yepez offered us in 2005, some proprietors, including the secondgeneration producer Richard Calderón, who employed more than fifty seamstresses, collaborated only minimally. Such skeptics saw little chance of attracting crowds to Atuntaqui for something as vague as fashion. In the event, they were wrong. More than twenty thousand visitors arrived in the first year.

Next, flushed with the success of the first Expoferia, the mayor urged the fair's organizers to form a chamber of commerce. He wanted an in-

1. Quotation from the development funding application "Solicitud de cooperación técnica no reembolsable," by the Atuntaqui Chamber of Commerce, May 2004 (our translation). 
Table 1 Contrast between Commons-oriented Stewardship and Cluster-oriented Strategic Cooperation

\begin{tabular}{lll}
\hline Characteristics & Stewardship & Strategic cooperation \\
\hline $\begin{array}{l}\text { A. MARKET PRACTICES } \\
\begin{array}{l}\text { 1. Exclusivity of producer } \\
\text { identity }\end{array}\end{array}$ & $\begin{array}{l}\text { Inseparable from } \\
\text { community or } \\
\text { cultural identity }\end{array}$ & $\begin{array}{l}\text { Private and protected } \\
\text { by law }\end{array}$ \\
$\begin{array}{l}\text { 2. Exclusivity of product } \\
\text { designs }\end{array}$ & $\begin{array}{l}\text { Innovation enhances } \\
\text { image of rivals' } \\
\text { goods }\end{array}$ & $\begin{array}{l}\text { Innovations distinguish } \\
\text { goods from rivals, } \\
\text { decreases value of others }\end{array}$ \\
$\begin{array}{l}\text { 3rimary asset } \\
\text { Value of civic space for } \\
\text { private enterprise }\end{array}$ & $\begin{array}{l}\text { Neutral, sales and } \\
\text { marketing independent } \\
\text { of firm home base }\end{array}$
\end{tabular}

B. JOINT ACTION, IMPROVEMENT PROGRAMS, PRODUCER COOPERATION

4. Money as condition of participation

5. Community identity as condition of participation

6. Resource-specific initiatives

7. Firm-specific initiatives

8. Regulation of economic boundaries

9. Payoffs to cooperative actions
Participation in cooperative projects minimally restricted by financial resources Access restricted to community members Significant investments in place, joint marketing of product class

Few initiatives that directly affect internal firm operations Restrict access to key resources or customer base

Non-exclusive, potentially available to non-participating peers and future participants
The greater the investment of private resources, the greater the share of payoff Community membership not relevant Few initiatives aimed at overall market

Most initiatives aim to improve internal capacities Remove boundaries, meet external standards, open markets Fully divisible among specified partners in cooperative venture

stitution that would promote further collaborations specifically among Atuntaqui's firms (table 1, characteristic 5). Providing the chamber with free office space, Mayor Yepez recruited Calderón to be president.

Calderón and Yepez then took the private-public formula to the next level, garnering international donor support to retool apparel production. To try to achieve up-to-date, fashionable clothing, they worked out an agreement with MICIP, consultants from the UN Industrial Development Organization, and a local university to develop a quality improvement 
program (Arcos 2006). With funding and technicians in place, they set out to radically enhance the manufacturing techniques of fifteen local businesses (table 1, characteristic 7).

Over the following two years, these business owners hosted weekly shop-floor visits. Consultants pushed the purchase of large cutting tables for laying out fabric, the use of templates for patterns, and the arrangement of sewing machines in efficient lines. Owners were flown to Chile and Italy to visit both apparel and tourism clusters. Arguing that business advantage lay not in secrecy but creativity, officials cajoled shop owners into allowing full access to their workshops for all other participants. This initiative proved so time consuming and intrusive that half the original firms dropped out. The results, though, were tangible. Some participating firms created new brands, others opened retail stores, and all hired on more workers. Success drew the original signatories back and resulted in a permanent, university-run office of technical support.

Consultants brokered narrow strategic alliances to address specific manufacturing or marketing issues. For example, four of the largest firms worked collectively to negotiate a discount on German-supplied computers and software to automate aspects of designing, sizing, and cutting (table 1, characteristic 9). The price was still steep. Each firm had to pay $\$ 18,500$. Yet when we interviewed each of the four firms in 2005, three of the four reported cost savings of 3 to 8 percent on material each month; all four reported being able to replace substantial labor time on cutting. The longest it took to pay off the equipment was eighteen months.

In 2005, the United Nations and MICIP organized tours to bring businesses from other Ecuadorian cities to Atuntaqui to learn how to develop by means of clusters. By the end of his tenure, Mayor Yepez chaired the northern Andean region's council on competitiveness. Perhaps most important, in our 2005 survey of Atuntaqui apparel businesses, we found that the sixty-eight largest sporting apparel firms employed 985 workersmore than the old factory did through the 1970s and 1980s. The textile tradition had passed from a single industrial plant to a new constellation of branded fashion outlets.

Having successfully turned the economic corner, Atuntaqui's recent growth nonetheless raises three concerns for both municipal authorities and some business owners. First, how far will standardizing production to international norms carry these businesses? In Atuntaqui in 2005, we found that the owner of the second-largest factory kept a computerized printout comparing his unit-per-worker output to levels achieved in Honduras, Vietnam, and China. However, the closer the workers came to the levels, the clearer was their problem. If they have to compete internationally on price, they will struggle to survive (Rivoli 2006). In September 2007, Atuntaqui proprietors circulated an article among themselves that indicated Chinese monthly wages to be roughly half of Ecuadorian wages. 
This news, in fact, came just after the Ecuadorian national textile association invited Atuntaqui entrepreneurs on an exploratory trip to China to meet with fabric producers and owners of production facilities (Atuntaqui Chamber of Commerce, August 2007).

Second, having opened their doors and remade their brands, how do operations achieve the creativity they promise as Ecuador's center of fashion? In 2005, when we asked one midsize producer with thirty employees whether he would use the chamber's proposed design facilities, he responded no. He reported that he had cut back his production to two styles of T-shirts and one sweatshirt so that he could keep his quantities up. Even the Expoferia paradoxically underplayed local designs. In 2007, for example, the evening fashion shows eschewed local firms and used the main catwalk to promote the out-of-town fashion-model revues X-Fashion and P.P.Q.P. Organizers delivered the sizzle of fashion without the substance of local design.

Third, as the technical assistance has shifted to supporting strategic alliances, broad goals of community development risk shrinking into narrowly targeted payoffs that are monopolized by the wealthiest firms. The chamber of commerce's own numbers underscore the problem. The chamber estimates that between 400 and 500 families produce cloth, clothing, or designs, yet only 140 textile firms have signed on as members of the chamber. Of these, between forty and seventy participate actively in Expoferia (sixty-six in 2007). Indeed, only fifteen received the full, direct benefits of the continuous quality improvement program. The four firms that emerged as owners of the computer design system in 2005 show how the public effort can ultimately cement a position of just a few enterprises. Further, these same firms have built on that collaboration to launch the new shared, high-quality brand Once in 2007. The new label signals Atuntaqui's continued entrepreneurial strength. Yet if the brand catches on nationally or internationally, few customers will necessarily know the town behind the brand. And with Chinese producers wooing companies, outsourcing is not out of the question.

In summary, development by means of clusters has left open basic concerns: how to achieve a distinctive identity for one's goods so that cheap imports cannot simply replace them, how to create something new amid the pressure to standardize, and how a community can build a trade in such a way that the a few successful ventures do not ultimately internalize the benefits. Potential answers to these issues lie down the Pan-American Highway in Otavalo.

\section{OTAVALO TEXTILES AND THE MAKING OF A MARKET COMMONS, 1960s-2000}

Connected to international markets since the 1940s, Otavalo craft production reached the peak of its modern expansion in the 1990s. Regional 


\section{Latin American Research Review}

weaving traditions, the end of indentured agricultural labor, the growth of tourism, and the ease of intercontinental travel all came together to jolt a provincial handwork tradition into high gear (Meisch 2002). If Atuntaqui's textile economy has been shaped by the legacy of the factory, Otavalo's has been stamped by an open-air market known to all as the Plaza de Ponchos.

Once a dusty square on the northern edge of town, the Plaza de Ponchos was home to a weekly market for both artisan goods and basic household necessities from early in the twentieth century. ${ }^{2}$ In 1973, municipal authorities worked with a Dutch aid agency to pave the plaza and erect flat, octagonal, concrete kiosks. In this austere new form, the plaza has served a double function, enabling retail trade to tourists and bulk trade among indigenous manufacturers and intermediaries. As tourists began to buy from Otavaleños, weavers diversified away from ponchos. Accepting tutelage from Peace Corps volunteers in the 1960s, and partnering with hippie entrepreneurs in the 1970s, Otavalo's artisans found ways to turn basic weavings into wall hangings and bags. Soon they became adept at marketing hand-knitted woolen sweaters, another Peace Corps product, and began selling growing quantities to other Otavaleños who traveled to sell handicrafts in Europe.

Having made their town synonymous with indigenous handicrafts, entrepreneurs pushed the boundaries of that category. Working with acrylic and polyester raw material, producers started businesses in hammocks, tablecloths, and embroidered shirts. Mechanized sweater production grew dramatically. In little more than a decade, twenty-one families developed the combined capacity to produce more than 1 million sweaters a year (see figure 2). No profitable innovation could protect itself from the action in the plaza. Once rivals saw customers line up for an article, they rushed out their own version, turning one person's creativity into a trend and then one more Otavaleño cliché.

Indigenous handicrafts had achieved a whole new cultural and economic reality; the plaza had become an emblem of indigenous industry and cultural rebirth. Beyond selling and buying there, the plaza's users began to take a deeper interest in its future. Indeed, in Otavalo, caring for the plaza became a way to defend a shared economic base-their "shared interests, which include lasting resources, produced things and ideational constructs" (Gudeman 2001, 7). The Otavaleños' concern reveals the way a market can give rise to a commons focused not on forests or fisheries or pastures, but on ideas.

Commons has become a fashionable term. In response to Hardin's (1977) famous essay that condemned the possibility of rational individuals living from shared resources, many scholars have documented numerous

2. The textile industry and entrepreneurial culture of Otavalo is extensively documented (Buitrón 1947; Colloredo-Mansfeld 1999; Korovkin 1998; Meisch 1998; Salomon 1981). 


\section{-- $\square$ - - Investment in New Capacity (per day) $\quad \triangle$ Total Capacity (per day)}

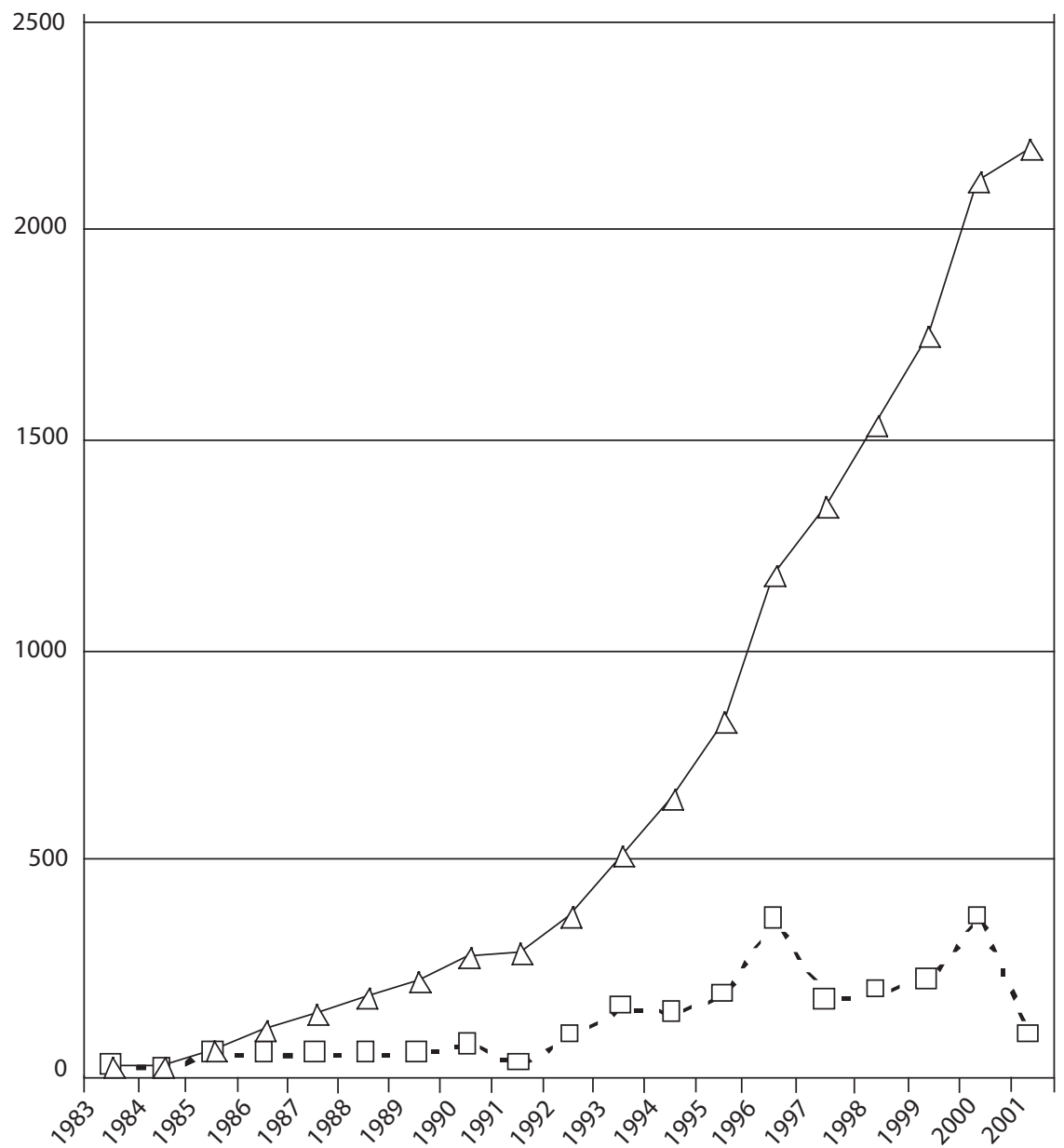

Figure 2 Growth in Sweater-Manufacturing Capacity of 21 Family Firms, Otavalo, 1980-2001

ways that communities, in fact, avoided tragedy and successfully managed resource systems (Acheson 1989; Agrawal 2002; McCay and Acheson 1987; Ostrom 1990). Conversely, with markets tapping ever more natural resources, scholarship has shown where commons do falter. Privatization, overcapitalized production, or ill-conceived state management plans have brought many common-pooled resources to the point of collapse; community institutions have struggled to keep up (Acheson and Gardner 2004; Agrawal 2003; Dolsak and Ostrom 2003; McCay 2002). 


\section{Latin American Research Review}

But those concerned with the fate of the commons now have even more to worry about. Nonini (2006) argues that along with natural resource commons, social, cultural, and intellectual commons are also at risk. In this expanded view, a commons represents an assemblage that people hold in trust to use on behalf of themselves, for past and future generations to make biological, cultural, and social reproduction possible (Nonini 2006, 164). All commons, Nonini argues, have come under threat of dispossession. Writers on law, popular culture, and technology, for instance, have rallied to defend the digital commons. Excited by the generative possibilities of electronic media, digitizing culture, and Internet connectivity, they have fought to keep trademark and copyright laws from privatizing a vibrant, shared cultural space (Lessig 2001; McLeod 2001). ${ }^{3}$

Much of this new scholarship on cultural commons, though, dodges key practical issues. Work on digital culture, for example, celebrates the creative power of sharing without explaining how people might actually make a living from their efforts. The work on shared cultural property rights, on the other hand, examines the ins and outs of owning culture without offering a clear idea of how new cultural artifacts emerge, evolve, and yet remain characteristic of a people. Nonini $(2006,167)$ points out that, unlike natural resources, cultural resources depend on intense and frequent human involvement for their regeneration. Otavalo offers a useful view into how communities generate and regulate cultural resources that hold economic value. Specifically, the commons-like reality of this resource system lies in three key characteristics: (1) nonexclusivity of commercial innovation and identity, (2) community-mediated access to resources, and (3) community management of a shared resources. But perhaps the best evidence for the commons is negative. Otavalo's market has declined since the late 1990s and its failure has been "tragic" (as Hardin would have it) in two key ways: a number of local producers have acted as free riders, running down what others built up, and Peruvian producers have arrived, breaching the boundary that fostered an identity among people, trade, and place. We elaborate on these five features below.

\section{Coinnovation}

Designing goods in Otavalo has always been nonexclusive, a sort of joint venture that results from an unending sequence of mutual robbery. As one acrylic sweater producer reported in 2001, "Everyone copies. We

3. The defense of shared stockpiles of ideas, though, can apparently pit one commons against another. Thus, as indigenous people have sought to defend their shared cultural heritage-spanning medicine, art, and places_-from the trademarks and patents of private corporations they seem to be enclosing sections of the global cultural commons (Brown 2003; Coombe 1998). 
are not egotistical. It is a free market." At the time of this producer's comments, the showrooms of acrylic sweater makers started to display figures of eagles, war bonnets, and other motifs of Plains Indian culture-goods Otavaleño travelers were selling in North America. Within two to three years, these designs could be found in every venue that sold acrylic sweaters. By 2006, shirtmakers had copied and miniaturized the same designs, embroidering them onto cotton shirts. Powwow regalia became part of the palette of indigenous Andean identity. Observing the same sort of copying and regularity of displayed designs in African art markets, Steiner argues for the importance of imitation. He writes that as artisans converge on a limited number of designs, they communicate via "the sobering force of repetition with relative clarity and precision" (Steiner 1999, 101). This seriality authenticates goods and affirms the coherence of a market niche (table 1, characteristic 2).

As cultural conventions emerge amid a struggle for sales, competition becomes inclusive. That is, even as they compete to win business from rivals, producers enhance symbols, places, historical narratives, and commercial reputations, which the wider community uses to attract customers and distinguish their goods (Colloredo-Mansfeld 2002). Painters and artisans from Tigua, Ecuador, for example, borrowed from one another's art and sales techniques so consistently in the 1970s and 1980s that they created an art form that gallery owners came to describe as native Indian art. They settled on appropriate themes, honed the technique of using sheep-hide canvasses, and defined the settings in which Tigua art could be found. In short, they created a rich symbolic world that attracted sales. Otavaleños have done the same. In a given transaction, one vendor may walk away with the profits, but part of the value of the exchange stays in Otavalo's plaza for others: the commodity design will carry over into versions brought out by rivals; the fame of this market as both native and novel will continue and draw future visitors. All of this is what one would expect of a weekly market of unknown artisans and traditional crafts. In Otavalo, though, artisans may own tens of thousands of dollars worth of machinery, have created their own brand, and have long-standing deals with chain stores in Europe. Yet for all the private investment, the value of one's business remains inseparable from one's predecessors, one's competitors, and one's place of origin (table 1, characteristic 1).

\section{Community Access}

To get a piece of this value, one need not be a native Otavaleño-merely persistent, patient, and faithful to the weekly market. To be sure, the great majority of market stalls in the plaza and surrounding streets have been controlled by and traded among Otavaleños for generations. Yet mestizos from Otavalo, indigenous people from other provinces, and in recent 
years, refugees from Colombia have become regular market participants. Money and connections can help secure access to more valued spaces. Yet hard work has carried some far. A number of indigenous Tiguan painters - artisans with little capital-have become a permanent feature of the market by dint of their regular participation since 1992. Access, of course, does not mean success. Indeed, the real money is usually made through bulk wholesale deals, many of which pass through stores in the neighborhood around the plaza rather than the plaza itself. Yet access to a market stall may be the most valuable, or the only, economic asset some in Otavalo have (table 1, characteristic 3).

\section{Community Management}

Long aware of the value of the power of their market, Otavaleños have sought to manage it. By 1988, they had founded the UNAIMCO. The group first busied itself with resolving disputes over market-space allocation. It offered documentation for the inheritance of a market stall or the sale of rights of use from one artisan to another so that the city would recognize the new owners and, by extension, the customary system of space allocation. More mundanely, UNAIMCO organized the cleanup of the plaza, the placement of trash cans, and the provision of shared phone service.

Since 1996, though, the artisan union has invested more of its money and effort in cultural management than in economic programs. Members organized the activities of the annual Fiesta of San Juan, or Inti Raymi (the Festival of the Sun), which marks both summer solstice and the completion of the maize harvest. Traditionally, groups of men celebrated in the countryside by dressing in costumes and going from house to house in the dark, to play music and dance until receiving food and drink. Reinventing the fiesta, UNAIMCO raised funds to cook cauldrons of soup and sent out invitations to rural councils. In response, they received hundreds of dancers at a stage in the Plaza de Ponchos. Thus, UNAIMCO succeeded in stamping the market with a festive indigenousness, upholding a cultural boundary of a group of trades. Unfortunately, its authority in recent years has stopped short of being able to sanction destructive competition within this boundary.

\section{Free Riders}

The shared value created by Otavalo's busy artisans has never seemed more obvious than when they have jeopardized it. The Plaza de Ponchos has begun to fail Otavaleños in recent years, and artisans experience that decline as the collapse of a resource system. More tellingly, they point to their own misdeeds as a source of the problem-despite the obvious harm caused by external factors, including the dollarization of the economy. 


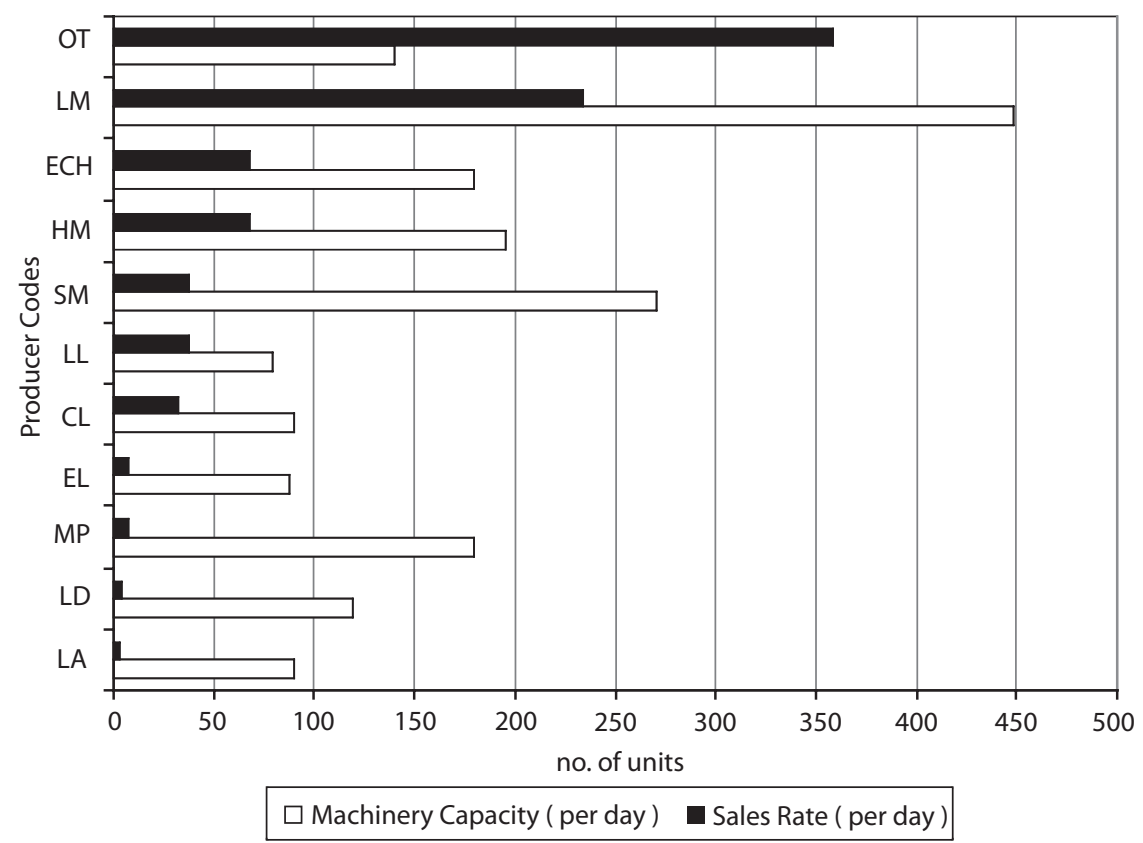

Figure 3 Machinery Underutilization in Wake of Dollarization in Top 11 SweaterManufacturing Operations, Wholesale Sales Recorded June-July, Otavalo, 2001

Indeed, in the first year after the abandonment of the national currency and the adoption of the U.S. dollar, sales fell for everyone. The acrylic sweater makers, who had been in the fastest-growing business in Otavalo, were hit particularly hard, with most producers reporting severe underutilization of their machinery (see figure 3). Only one firm remained in an expansionary mode, with sales outstripping capacity. It attributed its success to having a family member in Spain who sent back particularly fashionable color choices. Interestingly, this same family had a very open ethos. Admitting freely that she copied from her rivals, the proprietor also hung all her latest designs and colors out across her showroom windows for any and all of her competitors to see. As figure 3 shows, though, such successes were rare.

At first, UNAIMCO responded forcefully, coordinating a boycott of suppliers to stabilize prices. Subsequent protests against the fiscal reforms, though, stalled. As both union leaders and many artisans themselves acknowledged, the dollarization was not at the root cause of their problems. Rather, as one union leader put it, Otavaleños were "burning the market" through "disloyal competition" among themselves. Disloyalty in fact covered two misdeeds: imitations sold at a lower price and poorly made goods that gave everyone a bad reputation. One acrylic sweater maker 
reported in 2001: "To get new designs, it is not easy; you have to 'puzzle it out.' Recently, I developed three new designs. I wanted to send these directly abroad so that no one would copy me. But what happened? An intermediary picked them up [and brought them to another producer] and already within two weeks there were copies. These people had copied the figures exactly. And now because of the competition the price drops."

The artisan was referring specifically to a figure called cara del indio that he had spent two months planning out on graph paper and several hundred dollars to have programmed. It went on to become the most popular new design in the summer of 2001. And while his rivals brought out identical versions, he shut down his workshop and began selling off the $\$ 120,000$ in knitting machines he had accumulated.

Poor quality compounds the ills of copying. Another acrylic sweater producer described a customer of his from New York who once balked at the price of a one-thousand-unit sweater order. "The client went and bought them in the plaza," the manufacturer reported in 2001. The client later discovered that the sweaters were badly made: "the wool in the torso was [eighty] grams too light, the sleeves were twisted." The producer said that the former client ended up throwing all his rival's goods away. "In the plaza there are no guarantees," the sweater maker observed. Where conscientious producers worked to sustain a reputation for quality, their underhanded competitors have reaped the gains. They arrive in the plaza with poorly made goods, sell them at a discount, pocket all the profit, and saddle the marketplace with a reputation for shoddy crafts. The oftrepeated phrase "burning the market" aptly captures the sense of a short, rapid capture of the energy of the market, leaving ashes for those who follow.

\section{Failed Economies Boundaries}

Researchers who have worked on natural resource commons have emphasized the importance of stable property rights-boundaries on the pooled resources-as a condition of effective management and stewardship (table 1, characteristic 8). As McCay and Acheson $(1987,11)$ have suggested, a starting point for the protection of a common-pooled resource is this idea: "If we can keep others out, it makes sense for us to do something about our behavior." Otavaleños have recently found it impossible to keep others out. In particular, craft resellers from Peru have changed the dynamic of the market. At first, Peruvian goods arrived in town via Otavaleño intermediaries who returned from sales trips to Lima with alpaca sweaters. Then Peruvian resellers began to travel to Otavalo to strike deals with local intermediaries, who found outlets for them both in the plaza and among the travelers who sold crafts abroad. After a border dispute between the two Andean countries was resolved in the late 1990s, 
Peruvians themselves began to travel freely in Ecuador. Consequently, by 2001, at least eighteen Peruvian-owned shops had opened in Otavalo on streets near the Plaza de Ponchos.

With the Peruvians now taking over the distribution of their products within a market built up by Otavaleños, the Ecuadorians tried to push back. In July 2001, more than 150 Otavaleño market vendors signed a petition requesting a tax investigation of the Peruvian stores, with the goal of shutting them down. The spokesman for the Otavaleños put the case as follows:

The worry is this. First, two or three years back, the Peruvians were arriving and locating themselves in different hotels. They were arriving and with the merchandise that they were bringing, they always handed it over to the Ecuadorians, to the Otavaleños, better said, to those who worked in the market. So Peruvian crafts were sold by the Otavaleños to the thousands of compañeros who sell outside the city, for example in Quito, Ambato, Riobamba. We have even sent Peruvian crafts to other countries. Unfortunately, in this past year, they have opened many shops.... In the past, the Poncho Plaza was good. Now, the market does not even give us our daily bread. Now one earns a quarter of the bread that one gives to our children. For this reason, we are concerned to shut the stores of the Peruvians.

For the UNAIMCO, the guardians of Otavalo's Plaza de Ponchos, the Peruvian problem has been intractable. In a meeting of the union's board members in the days after they received the petition, the president reminded the other officers that Ecuador has signed the Andean Pact and several bilateral agreements specifically with Peru. "How can we throw anyone out?" he rhetorically asked.

In 2005, municipal authorities began to acknowledge the severity of the craft economy's problems. In keeping with contemporary models of development, Otavalo's leaders embraced the importance of competitive advantage as a solution. In the summer of 2005, officials recruited members of UNAIMCO's board of directors to work with a team of national consultants on the Participatory Appraisal of Competitive Advantage (PACA) project. The project promised "to identify viable actions to reinforce the competitiveness of economic sectors and local businesses." ${ }^{4}$ Led by specially trained residents, people joined in workshops to assess the components of their competitive environment.

The four weeks of PACA meetings and workshops turned up few new insights, though. Having enumerated the strengths and weaknesses of their market, PACA participants arrived at suggestions that ran from the mundane (better signs along the Pan-American Highway) to the quaint (donkey tours of indigenous communities). Many artisans in Otavalo talked about the need for more training. Indeed, they specifically noted the

4. From the PACA PowerPoint presentation, "Como estimular el desarrollo económico local/regional?" given in Otavalo, in June 2005. 
turnaround in Atuntaqui through its recent initiatives. After PACA (and with encouragement from our research team), UNAIMCO even went so far as to contact several of the same institutions that worked in Atuntaqui to run a workshop on fashion cycles. Yet neither leaders nor members of the union wanted to set up the invasive workshop visits or the intensive strategic alliances to negotiate with suppliers.

Instead, Otavaleños sought a robust defense of the identity at the heart of the economy: the link among people, place, and crafted goods they inherited from their parents and that they hoped would provide for their children. Thus, to regulate their own-destructive behavior-the disloyal competition-members of the union argued for a municipal-backed Otavalo seal of quality. The mayor and the union had been talking about the possibility, and some used the PACA meetings to plead for a tangible label that producers could use to show their commitment to quality. So, too, having complained about the deteriorating condition of the plaza during the PACA meetings, an architect with the union eventually developed plans by 2007 to use pre-Columbian inspirations to resurface the market, introduce statues, and build a stage. And the fight to exclude the Peruvians has only grown more acute. In 2007, UNAIMCO joined other local organizations and drew up a petition that began its demands as follows:

The present ordinance protects the culture and identity of the ancestral productive and folkloric activities of the Quichua People of the Township of Otavalo and all of its communities, whether artisanal or of other type.

In the formal and informal artisan fairs, specifically in the Plaza de Ponchos of the jurisdiction of the Township of Otavalo, one will vouch for the sale of original products made in Ecuador, preferably from this locality. One will not allow the sale of foreign products that have entered illegally without permission or duties or taxes required by law.

On October 22, 2007, about one thousand artisans from throughout the province marched in the streets of Otavalo to protest the Peruvians and to present the petition to municipal authorities.

If one were a pessimist, Otavalo's struggling Plaza de Ponchos can be read as one more instance of the wearing down of the commons (Nonini 2006). Once an epicenter of cosmopolitan culture and a dizzying industry of craft production, the market risks becoming an outlet of imported goods and timeworn designs. The state's policies have hurt. Liberalization of borders and hard-currency reforms compromised the conditions that helped the market grow. And while state agencies supported Atuntaqui producers with money, experts, and years of training, they offered but four weeks of training in Otavalo. Although they are fully aware of such inequities, Otavaleños also acknowledge their own hand in their decline, especially the problems of disloyal competition.

Yet there are grounds for optimism, too. Shirtmakers, for example, are still introducing new designs and gaining new customers. The artisan 
union and others have been steadfast in their commitment to producing goods with identity, to reinvigorating the plaza, and to prioritizing the rights of local residents so they are able to earn their daily bread by selling those products in that plaza. To be sure, in Atuntaqui, the cluster initiative has offered a sound example of constructing relationships among rivals through strategic cooperation. However, Otavalo offers evidence of an alternative, long-term orientation to defend the viability of a shared economic home base.

The approaches of each group of producers-commons-oriented stewardship and cluster-oriented strategic cooperation-differ in general terms by their emphasis on shared assets or the private capacities of firms. However, it would be a mistake to view these two orientations as opposed. In many important aspects they are, in fact, mutually dependent rather than exclusive. The greater the successes due to strategic cooperation, the more likely is the growth of cultural conventions that distinguish producers, enhance goods, and enliven a place. The commons perspective recognizes both the necessity of these resources and that they accrue to the collectivity, not individual firms. Further, they are potentially just the set of assets that distinguish producers and their laborers so as to offer a more defendable niche in the global economy. Indeed, as Atuntaqui has built on its successes in recent years, its model seems less and less focused on strategic alliances. Rather, town officials and business owners seem to be building their own cultural commons.

\section{ATUNTAQUI'S NEW “WE"}

Since the late 1990s and in parallel to the programs sponsored by MICIP, families in Atuntaqui had been engaged in their own inclusive competition, transforming the city center through a surge of investments in individual showrooms (see figure 4). Previously, the town offered a few discount sales outlets. Most were small and dark, looking like converted school supply shops. The new stores, in contrast, feature bright display windows and spacious interiors, making fashion a street-level experience.

Both the chamber of commerce and city hall have reinforced the value of these efforts. In 2006, for example, municipal authorities rebuilt a portion of the main square so that it could be used as a staging area for fashion shows and cultural events. They have also commissioned plans to partly pedestrianize one of the two main commercial avenues. With wide sidewalks tiled in bright colors, illumination from decorative lampposts, and other upgrades, the town itself will take on a shopping mall aesthetic.

The chamber of commerce for its part has relocated the Expoferia. It used to rent the high school on the edge of town and set it up as a conven- 


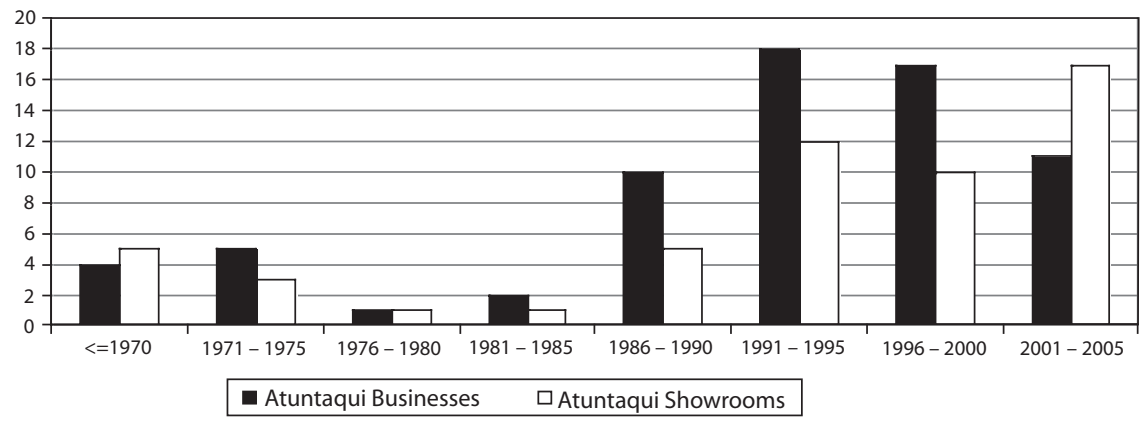

Figure 4 Growth in the Opening of Showrooms in Atuntaqui, 1965-2005.

tion hall with booths for exhibitors. Beginning in 2006, it made the core twelve blocks of the city into the convention hall. Shutting the downtown area to vehicles and setting up a catwalk for fashion shows and dance acts in the central park, the chamber let all downtown businesses in on the tradeshow traffic. Most interesting is that seven firms responded to the open Expoferia by closing their relatively new stores and opening new permanent locations in the fair district. The combined efforts of firms, trade association, and city government are remaking the town into a fashion landscape, creating a civic asset to assist private ones.

City hall's embrace of textile enterprise spills over to its work in tourism and culture. When Mayor Yepez's staff began to develop economic programs, they also drew up plans to convert the abandoned factory buildings into a textile museum. The competitive advantage they sought for sweater makers would be matched by claims for a unique cultural history. Economic and cultural differences would draw life from each other. The director of culture and tourism explained in 2005: "When people think of Imbabura Province, of the history of the people, they think of Otavalo and Cotacachi and that the history is indigenous. But it is not like that here in Atuntaqui. We have our own history."

The factory embodies it. As the monument consecrating a "we" distinguishable from the provinces' more renowned indigenous districts, the factory adds the weight of history to recently opened T-shirt shops. The vice president of the chamber of commerce told us during a tour of the factory grounds in 2005, "People think we are only five years with this business [i.e., since the advent of the modern Expoferia]. But it is not like that. From the time we are born, we are textileros (textile producers), from eighty years ago." By burnishing the symbols of who they are, residents hope to perpetuate the value of what they make. Identity and culture, in fact, have been elevated to be the central node of Atuntaqui's development under the new mayor Richard Calderón, the erstwhile president of the chamber of commerce, who was elected in 2005. In the strategic plan of develop- 


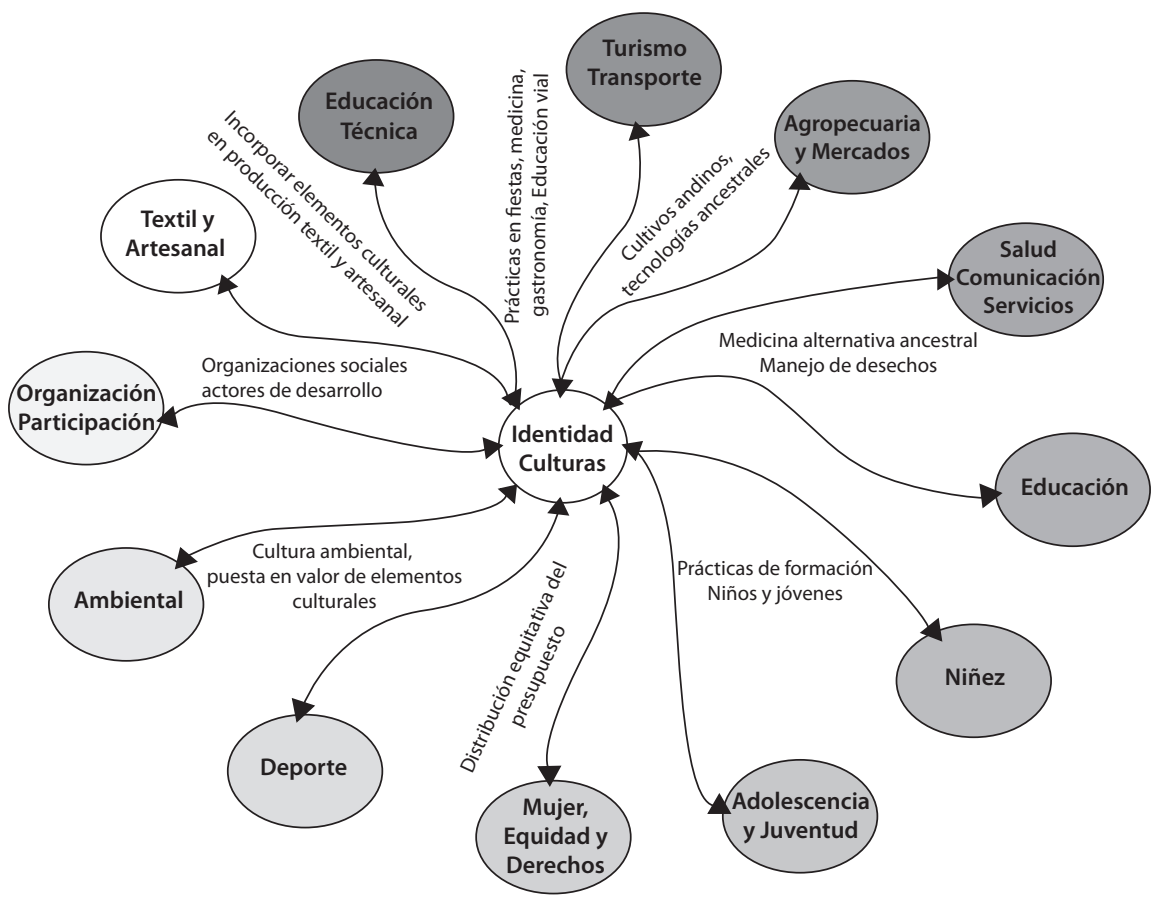

Figure 5 Schematic Representation of the Place of Identity in Atuntaqui's Strategic Development.

Source: Plan estratégico de desarrollo cantonal (Atuntaqui, Ecuador: Gobierno Municipal de Antonio Ante, 2006).

ment published at the end of his first year in office, identity was singled out as the touchstone of the twelve other concerns of his administration (see figure 5).

\section{COMPETITION, CLUSTERS, AND COMMONS}

Ecuador's community competitiveness initiatives were instructive moments in the history of bringing neoliberal capitalism to the people. Saddled with the hardest currency in South America, Ecuador lost jobs to its neighbors, its citizens to emigration, and its political stability to popular unrest. In Atuntaqui, Otavalo and thirteen other municipalities, the state responded by training people in the paradigm of competitive advantage developed by a Harvard Business School economist.

Atuntaqui made far more of the message of competition and cooperation than did other localities. In 2001, the cluster message was a relatively easy sell in the old factory town. Proprietors embraced collaboration in part because it built on familial and social ties that crosscut apparel op- 
erations, city hall, and the chamber of commerce. Yet to their credit, they went further than ever before to support a program of shared improvement. In four years of sustained effort, many shops modernized production, lowered raw material costs, and developed fashionable brands. Yet for all the economic gains, business leaders and town officials worry about the future. They are especially concerned about cheaper Asian imports. In fact, the success of the cluster initiative itself has led to the emergence of a small set of firms with distinguishable brands that could now outsource to China. The more the cluster project has come to focus on narrow, strategic alliances among top firms, the less tied the benefits are to Atuntaqui and the public institutions that nurtured them.

Otavalo's development has offered a useful contrast in the growth of a place-based economy: the cultural commons. The culture at stake involves, in part, values that facilitate a respect for (loyal) competition and entrepreneurship. Culture also entails the stockpile of shared ideas-the inherited creative legacy of an indigenous people. Yet the cultural dimension of this Andean commons goes beyond both values and heritage to generative habits that inhere in ongoing economic practice-it is part and parcel of designing goods, presenting products, competing for business, and earning a livelihood. Thus, a cultural commons perspective reframes the mutual dependence recognized in cluster initiatives in a more intrinsic way. At heart, it pushes people to identify that core characteristic that sets their efforts and community apart: what is it that both gives meaning to lives and value to products?

In Otavalo, such a characteristic is tied up with native Andeanness. In Atuntaqui, town authorities and apparel entrepreneurs have arrived at their own sense of identity, of being a modern textilero. Public and private investments in each place substantiate these identities in retail landscapes, civic events, museums, fiestas, and other efforts that preserve a unique history. In this article, we speak of the ideas and identities reproduced in these ways as a cultural commons to underscore that they are resources that producers hold in trust from previous generations, that transcend individual firms, and that cannot be effectively privatized. We also use the term commons to call attention to the ways they need to be defended to foster continued growth.

Indeed, the idea of a cultural commons pushes development projects to take seriously the idea of economic stewardship. Among other measures, projects need to seek out those individuals, firms, or voluntary organizations that have acted as stewards. Having mentored new entrants into traditional trades, promoted civic identity, and preserved the diversity, even idiosyncrasies of local production, such stewards can offer to their work and products a distinctiveness that modernization efforts alone fail to. Second, a commons perspective would take seriously issues of comanagement, a joint effort between community authority and the state. Crucially, 
such comanagement would recognize constructive ways of defending cultural-economic boundaries. In such a scheme, outsiders could not indiscriminately tap the economic value built up in place in the name of free trade. Offering a level of protection need not mean total exclusion. Rather, it may entail getting newcomers to contribute to the collective good that others have generated and that these outsiders in fact seek to live from. Finally, when officials can preserve meaningful boundaries, development efforts should support local authorities' efforts to promote creative competition among insiders and sanction destructive practices-to develop the tools such as Otavalo's hoped-for seal of quality.

Although our article's title implies the limits of competition-driven development, we are not in fact anticompetition. In Atuntaqui, theories of competitive advantage have been applied in creative ways. The economic successes are real. In Otavalo, competition has long been culturally generative, creating meaning, differences, things, and places that are integral to Otavaleño identity. Yet competitive dynamics in both towns are not enough in themselves to overcome shortcomings specific to each economy. The experiences of both places have shown that successful economic development will entail cultivating the commons that underlie firms' competitive positioning and strategic cooperation.

\section{REFERENCES}

Acheson, James M.

1989 "Management of Common Property Resources." In Economic Anthropology, edited by S. Plattner, 351-378. Stanford, CA: Stanford University Press.

Acheson, James M., and Roy J. Gardner

2004 "Strategies, Conflict and the Emergence of Territoriality: The Case of the Maine Lobster Industry." American Anthropologist 106 (2): 296-307.

Agrawal, Arun

2002 "Common Resources and Institutional Sustainability." In The Drama of the Commons, edited by E. Ostrom, T. Dietz, N. Dolsak, P. C. Stern, S. Stonich, and E. Weber, 41-86. Washington, DC: National Academy Press.

2003 "Sustainable Governance of Common Pool Resources: Context, Methods, and Politics." Annual Review of Anthropology 32: 243-262.

Arcos, Xavier

2006 "Results of Unido Project Aimed at Supporting Clusters in Textiles and Garments. “ Unido Document No. 57219 (accessed August 2007, at http://www.unido.org/ doc/57219)

Bourdieu, Pierre

1998 "The Myth of 'Globalization' and the European Welfare State." In Acts of Resistance: Against the Tyranny of the Market, 29-44. New York: New Press.

Brown, Michael F.

2003 Who Owns Native Culture? Cambridge, MA: Harvard University Press.

Buitrón, Aníbal

1947 "Situación económica y social del indio otavaleño." America Indígena 7 (1): 45-62.

Caniëls, Marjolein C. J., and Henny Romijn

2004 "Technology Learning in Small Enterprise Clusters: Conceptural Framework and Policy Implications." In Innovation Learning and Technological Dynamism of Developing Countries. Edited by Sunil Mani and Henny Romijn, 135-137. New York: United Nations University Press. 


\section{Latin American Research Review}

Colloredo-Mansfeld, Rudi

1999 The Native Leisure Class: Consumption and Cultural Creativity in the Andes. Chicago: University of Chicago Press.

2002 "An Ethnography of Neoliberalism: Understanding Competition in Artisan Economies." Current Anthropology 43 (1): 113-137.

Comaroff, Jean, and John L. Comaroff

2000 "Millennial Capitalism: First Thoughts on a Second Coming." Public Culture 12 (2): 291-343.

Consulado General del Ecuador en Montreal

2003 New Bulletin No. 12, March 2003 (accessed September 2008 at http://www .consecuador-quebec.org/BOLTEIN\%20DE\%20PRENSA\%2012\%20ENGLISH .pdf).

Coombe, Rosemary J.

1998 The Cultural Life of Intellectual Properties: Authorship, Appropriation and the Law. Durham, NC: Duke University Press.

Dolsak, Nives, and Elinor Ostrom, eds.

2003 The Commons in the New Millennium: Challenges and Adaptations. Cambridge, MA: MIT Press.

Drabenstott, Mark, Nancy Novack, and Stephen Weiler

2004 "New Governance for a New Rural Economy: Reinventing Public and Private Institutions-A Conference Summary." In New Governance for a New Rural Economy: Reinventing Public and Private Institutions, 1-7. Kansas City, KS: Federal Reserve Bank of Kansas City.

Gudeman, Stephen

2001 The Anthropology of Economy. Malden, MA: Blackwell Publishers.

Hardin, Garrett

1977 "The Tragedy of the Commons." In Managing the Commons, edited by G. J. Hardin and J. Baden, 16-30. San Francisco: W. H. Freeman.

Korovkin, Tanya

1998 "Commodity Production and Ethnic Culture: Otavalo, Northern Ecuador." Economic Development and Cultural Change 47 (1): 125-154.

Lessig, Lawrence

2001 The Future of Ideas: The Fate of the Commons in an Interconnected World. New York: Vintage.

McCay, Bonnie

2002 "Emergence of Institutions for the Commons: Contexts, Situations, and Events." In The Drama of the Commons, edited by E. Ostrom, T. Dietz, N. Dolsak, P. C. Stern, S. Stonich, and E. Weber, 361-402. Washington, DC: National Academy Press.

McCay, Bonnie J., and James M. Acheson

1987 "Human Ecology of the Commons." In The Question of the Commons: The Culture and Ecology of Communal Resources, edited by B. J. McCay and J. M. Acheson, 1-34. Tucson: University of Arizona Press.

McLeod, Kembrew

2001 Owning Culture: Authorship, Ownership and Intellectual Property Law. New York: Peter Lang.

Meisch, Lynn A.

1998 "The Reconquest of Otavalo Ecuador: Indigenous Economic Gains and New Power Relations." In Research in Economic Anthropology, Vol. 19, edited by B. L. Isaac, 11-30. Stamford, CT: JAI Press.

2002 Andean Entrepreneurs: Otavalo Merchants and Musicians in the Global Arena. Austin: University of Texas Press.

Mitullah, Winnie

1999 "Lake Victoria's Nile Perch Industry: Institutions, Politics, and Joint Action." IDS Working Paper 87, Institute of Development Studies, University of Sussex, Brighton, UK.

Nonini, Donald

2006 "Introduction: The Global Idea of 'the Commons.'” Social Analysis 50 (3): 164-177. 
Nonini, Donald, ed.

2007 The Global Idea of "the Commons." New York: Berghahn Books.

Ostrom, Elinor

1990 Governing the Commons: The Evolution of Institutions for Collective Action. New York: Cambridge University Press.

Porter, Michael E.

1998 The Competitive Advantage of Nations. New York: Free Press.

2000 "Attitudes, Values, Beliefs and the Microeconomics of Prosperity." In Culture Matters: How Values Shape Human Progress, edited by L. E. Harrison and S. P. Huntington, 14-28. New York: Basic Books.

Rivoli, Pietra

2006 The Travels of a T-Shirt in the Global Economy. Hoboken, NJ: John Wiley and Sons. Salomon, Frank

1981 "Weavers of Otavalo." In Cultural Transformations and Ethnicity in Modern Ecuador, edited by N. E. Whitten, 420-449. Urbana: University of Illinois Press.

Schmitz, Hubert

1995 "Small Shoemakers and Fordist Giants: A Tale of a Supercluster." World Development 23 (1): 9-28.

Schmitz, Hubert, and Khalid Nadvi

1999 "Clustering and Industrialization: Introduction." World Development 27 (9): 1503-1514.

Steiner, Christopher B.

1999 "Authenticity, Repetition, and the Aesthetics of Seriality: The Work of Tourist Art in the Age of Mechanical Reproduction." In Unpacking Culture: Art and Commodity in Colonial and Postcolonial Worlds, edited by R. B. Phillips and C. B. Steiner, 87-103. Berkeley: University of California Press.

Trouillot, Michel-Rolph

1999 "Close Encounters of the Deceptive Kind: The Anthropology of the State in the Age of Globalization." Fiftieth Anniversary of the Founding of Anthropology at Stanford University, Stanford, CA.

Visser, Evert-Jan

2000 "Structural Adjustment and Cluster Advantages: A Case from Peru." In Local Economies in Turmoil: The Effects of Deregulation and Globalization, edited by A. Sverrisson and M. P. van Dijk, 77-94. New York: St. Martin's Press.

Wolfe, David A., and Matthew Lucas

2005 Global Networks and Local Linkages: The Paradox of Cluster Development in an Open Economy. Montreal: McGill-Queen's University Press and School of Policy Studies, Queen's University. 